Badrut Tamam, Slamet Setiawan, Syafi'ul Anam, Jihat Nurrahman,

Tell : Teaching of English Language and Literature Journal

Vol. 8, No. 1, 28 - 39, Doi: http://dx.doi.org/10.30651/tell.v8i1.4410

\title{
The Students' Perception towards Madurese Traditional Culinary-Based Teaching Materials of English for Higher Education
}

\author{
Badrut Tamam* \\ Language and Literature Education, Postgraduate Program, State University of Surabaya, Indonesia. \\ e-mail: badruttamamwildan@gmail.com \\ *Corresponding Author \\ Slamet Setiawan \\ State University of Surabaya, Indonesia. \\ e-mail: slametsetiawan@unesa.ac.id \\ Syafi'ul Anam \\ State University of Surabaya, Indonesia. \\ e-mail: syaiful.anam@unesa.ac.id \\ Jihat Nurrahman \\ Mathematics Education Program, STKIP PGRI Sumenep, East Java, Indonesia. \\ e-mail: jogjaniez@gmail.com
}

\section{Article History}

Received: 29 February 2020

Reviewed: 25 March 2020

Accepted: 9 April 2020

Published: 30 April 2020

\section{Highlights}

- The English learning material which was equipped with Madurese traditional culinary gets a positive perception and higher appreciation from the students

- In the field of English language teaching, the traditional culinary can be used as valuable materials which can help to promote and maintain local wisdom

\begin{abstract}
This present study aimed at describing the students' perception towards Madurese traditional culinary based teaching materials of English in higher education level in Sumenep Madura. This is a survey research which is triangulated with three instruments used in collecting data namely: observation field notes, questionnaire, and interview. The result showed that the English learning material which was equipped with Madurese traditional culinary got a positive perception and higher appreciation from the students in terms of materials' attraction, materials' usefulness, materials' difficulty, materials' variety, materials' authenticity, and proportion of the four language skills. Further, the students can happily and enthusiastically join the English language learning. They said that they could recognize the madurese culinary deeper than before. In addition, traditional culinary can be used as the identity that can promote the region to overseas. Moreover, in terms of English language teaching, the traditional culinary can be used as valuable materials which can help to promote and maintain local wisdom.
\end{abstract}

Keywords: Students' perception, English teaching materials, and Madurese traditional culinary.

\section{Introduction}

Maintaining and preserving local wisdom are the responsibility of every people in the community. There are some reasons why local wisdom should be preserved. First of all, it shows and also strengthens the identity of the people in that community in one area or island. As many people know that Indonesia has a lot of variety of cultures, religions, ethnics, local languages, tourism destinations, traditional foods and culinary, but the Indonesian people 
Badrut Tamam, Slamet Setiawan, Syafi'ul Anam, Jihat Nurrahman,

Tell : Teaching of English Language and Literature Journal

Vol. 8, No. 1, 28 - 39, Doi: http://dx.doi.org/10.30651/tell.v8i1.4410

have been unified in the diversity. It is in line with Indonesian tagline diversity and unity. The second, the existence of local wisdom indicates the existence of the community. One community will be seen popular and exist when they can promote and preserve their local wisdom. The third, it shows the togetherness in one group of community. It delivers message to people in other area that they are harmonious. These thoughts are supported by Nugraheni's idea et al. (2016). They suppose that local wisdom includes some characteristics and function such as (1) a marker of community identity; (2) elements of the social adhesive; (3) maintaining the existence of the community (4) coloring the community togetherness; (5) changing the mindset and reciprocal of individuals and groups; (6) encouraging harmonious togetherness, appreciation and shared mechanism to defend themselves.

One problem of teaching English in Indonesia is about the complexity to link between learning concepts and local wisdom. An observation result of previous study revealed that majority of teachers have difficulty to link the concept of teaching and local wisdom because the heritage of past educational systems in the field of language studies in the secondary level and higher education in Indonesia (Bakhtiar \& Nugroho, 2016). However, it should be taught integrated to create a new problem analysis. Theoretically, the concepts that are united by the theme of local knowledge will be easily comprehended by the learners.

Moreover, Some researchers (Bakhtiar, et al., 2016; Meliono, 2011; Nugraheni Eko, Wardani. Evy Tri, Widyahening, Raheni, 2016; Parmin, Sajidan, Ashadi, Sutikno, 2016; Sangiamwibool, 2012; Sajidan, S., Ashadi, A., \& Sutikno, 2015; Yoda, 2017) argued that the integration of local wisdom in the activity of learning possibly gave some benefits. It can raise learner's consciousness of local wisdom by relating the topic effectively in teaching and learning. So, it is very important to be applied in teaching English as foreign language in Indonesian context. While the students easily mastery the language concept at same time they also learn to recognize their national identity.

Madura is an island in East Java Province that has blessed with various tourism potentials (Suhaidi, Dewi, \& Muslim, 2018). One of them is culinary tourism. The culinary resources owned by Madura have given real description about the uniqueness and beauty of Madura Island that deserves to be tourist destination. Madurese traditional culinary has been known not only in local but also in international scope. It has been admitted that Madurese traditional culinary is very delicious. This recognition is supported by the increasing number of traditional restaurants in Madura that sell traditional culinary.

\section{Madura Traditional Culinary}

Madura has been widely known with various kinds of unique and delicious culinary. The uniqueness cannot be found in other places that's why a lot of domestic and international tourists come to that Island. Followings are the seven kinds of Madurese popular culinary that have been used for teaching English in the higher education as Madurese culinary based teaching materials: 


\section{Sate Madura}

Vol. 8, No. 1, 28 - 39, Doi: http://dx.doi.org/10.30651/tell.v8i1.4410

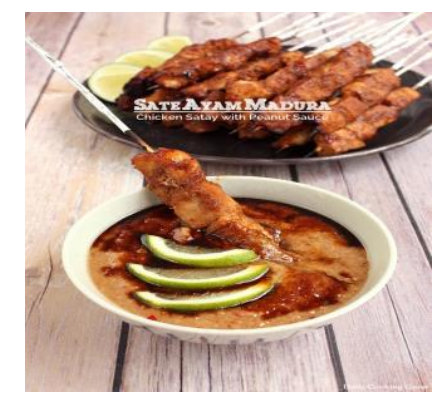

Sate Madura has been widely known in Madura and outside of Madura. In fact, Sate Madura becomes the idol food of many societies. The appetizing taste never makes people fed up to taste it. Sate has been promoted as part of very popular culinary tour in Madura. There are various kinds of Sate Madura namely Sate Daging Sapi, Sate Ayam, and Sate Kambing. (Adapted from Suhaidi et al., 2018).

\section{Soto Selingkuh}

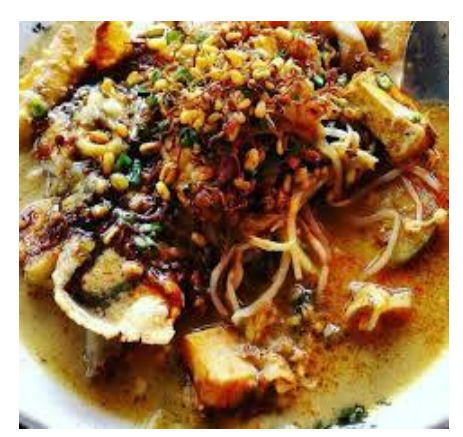

Soto Selingkuh becomes a special dish of Sumenep society. It is a unique food and different from other Soto in Java. The delicacy of Soto Selingkuh has made many people cannot stand to taste it. The flavour of Soto Selingkuh is very special, delicious, and very testy. Soto Selingkuh is blended ala Sumenep style. It mixes between Soto Babat and Rujak, so that, it resulted a satisfying taste. This popular Madurese culinary is available in a stall on Dr. Wahidin street, Pajagalan, Sumenep. (Adapted from Suhaidi et al., 2018).

\section{Kaldu Kokot}

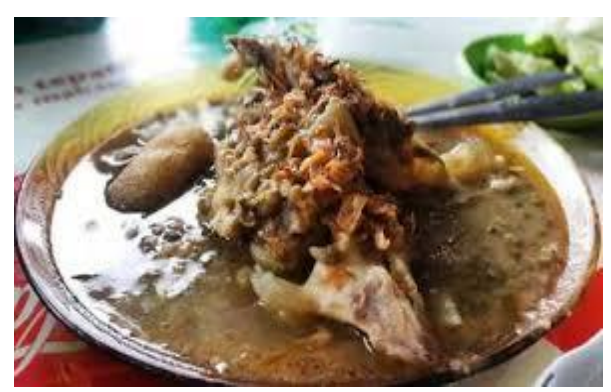

Kaldu Kokot is the most unique type of Sumenep culinary. Its uniqueness lies in its basic ingredients, namely green beans cooked with herbs. In terms of appearance, Kaldu Kokot looks like Maryam curry, a culinary that is often found in the religious tourism area of Sunan Ampel Tomb in Surabaya. Kokot is a Madurese language for the sole of cow or goat foot. For this culinary, the kokot served is cow feet. Parts of Kokot are filled with tendons, soft bones, and little tender meat. Kaldu Kokot is served in a dish with broth. Besides kokot, Kaldu Kokot sellers at several stalls also 
Tell : Teaching of English Language and Literature Journal

Vol. 8, No. 1, 28 - 39, Doi: http://dx.doi.org/10.30651/tell.v8i1.4410 mix with perkedel and ketupat. One portion of Kaldu Kokot is around 25 thousand to 35 thousand rupiahs. (Adapted from Suhaidi et al., 2018).

\section{Nasi Jagung}

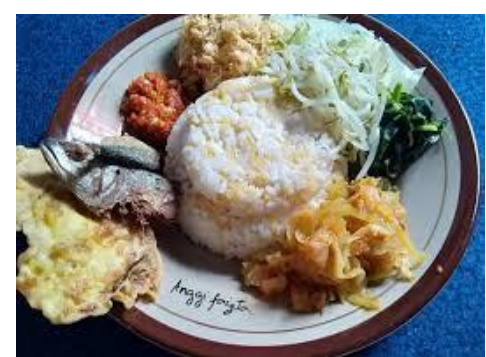

Nasi Jagung (rice mixed with corn) has become an iconic food of Madura societies. Currently, Nasi Jagung has become the pride of people from almost all social levels. The menu is no longer identical with the food of middle and lower societies. The middle and upper class societies also like to eat Nasi Jagung. Nasi Jagung is usually served with a variety of side dishes such as fried tuna fish, urap, and sambal (chilli). Nasi Jagung will be more delicious when it is served with soup of Kelor (Marongghi) leaves; a typical cuisine of Madurese people. Nasi Jagung is local and cheap culinary. (Adapted from Suhaidi et al., 2018).

\section{Rujak/Rojek}

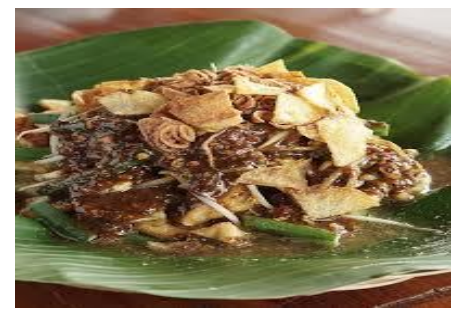

Unlike the salad (rujak) in general, Sumenep salad uses lontong, boiled cassava, cucumber, fried tofu slices, boiled vegetable consisting of water spinach long beans, sprouts, and cassava chips for topping. Ingredients mashed with fried peanuts are fish paste, seeded banana, vinegar from palm juice, salt and brown sugar. This culinary is easily found in the many districts of Sumenep. (Adapted from Suhaidi et al., 2018).

\section{Gettas}

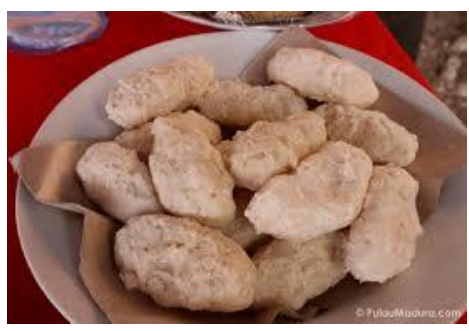

Gettas is included in a unique culinary because it is only exist at certain times or seasonal culinary and only 3 times in a year can be found at the time of Nyadar ceremony. Gettas is made from crushed sticky rice and mixed with great young coconut and then fried. After frying, the fried foods are covered with brown sugar and white sugar mixed with egg-white. Then the unique part is mixed with salt water. According to local residents, it is better to use salt water that does not contain iodine or raw salt produced from salt farmers directly from salt pond. This means 

gratefulness for God's gift because the farmer can harvest salt well. (Adapted from Suhaidi et al., 2018).

\section{Jubada}

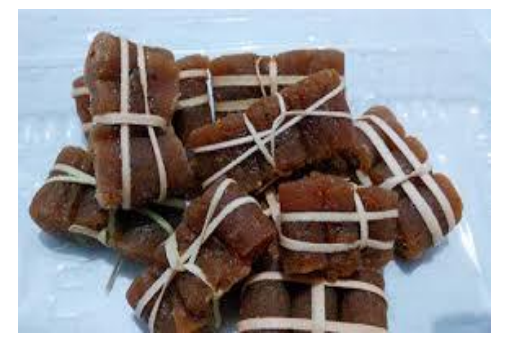

Jubada is a distinguished and unique Sumenep cake, especially for its flavour and shape. Jubada is made from glutinous rice flour mixed with brown sugar. Then, it is stirred with enough water then cooked until it thickens and shaped into long rolls. When it cools down, it is cut into some piecies, this cake is tied into three seeds of rolls using tiny rope made of Siwalan leaf. With its small size of about $2 \mathrm{~cm}$, this cake looks so unique. (Adapted from Suhaidi et al., 2018).

Some previous studies have attempted to elaborate their research related to local wisdom especially in the field of traditional culinary-based teaching materials in English Language Teaching (ELT) context. Aryanti (2010) with her qualitative design was discussing the use of Palembang's traditional culinary as teaching material through a theme-based language instruction. The result showed that the Palembang's indigenous foods were able support Palembang as a cultural hub, because the great numbers of the foods are well-known and spread not only in local but also national scope. In addition, teacher of English could participate in maintaining and preserving the foods as teaching materials.

The next study was conducted by Afifah (2015). The design of the research was Research and Development (R\&D) which aimed at: developing English learning materials by incorporating some cultural aspects; enhancing the internalization and actualization of cultural values; and improving English performance and competence of Junior High School Students. The results revealed that: the aspects of culture that were incorporated in the English Learning Material covered the reading topics, learning activities, culture corners, across cultures, let's play the games, and review; the values that were integrated in the texts were how to be discipline, responsible, honest, and patient. In addition, it showed a significant improvement toward students' English performance and competence.

Another study was action research conducted by Latupapua (2018). The study aimed at measuring the implementation of traditional culinary of Maluku in reading comprehension for understanding procedure text in English. Based on the result, the researcher found out that the reading competence of the tenth students of SMK Negeri 1 Ambon was highly improved. It proved that the students' understanding of procedure text better toward traditional culinary of Maluku.

In fact, these previous studies have not yet elaborated the students' perception toward the implementation of traditional culinary-based teaching materials of English especially in term of Madurese Traditional Culinary-based teaching materials. However, the students' perception is surely important to ensure the usefulness of the implementation. Therefore, the 
Badrut Tamam, Slamet Setiawan, Syafi'ul Anam, Jihat Nurrahman,

Tell : Teaching of English Language and Literature Journal

Vol. 8, No. 1, 28 - 39, Doi: http://dx.doi.org/10.30651/tell.v8i1.4410

students' perception towards Madurese traditional culinary-based teaching materials is necessary to investigate. Referring to the background stated on those previous parts, this research attempted to answer the following questions:

1. How are the students' perceptions toward Madurese Traditional Culinary Based Teaching Materials of English?

2. Is the implementation of Madurese culinary based teaching materials classified as a good way to preserve or maintain local wisdom especially in Madurese culinary?

\section{Theoretical Frameworks}

Tomlinson (2016: 1) argues that materials refer to anything that can be used to facilitate the students for learning a language, including course books, videos, $\mathrm{CD}$, flash cards, games, and so on. His ideas can be drawn out that materials may be formed in any kind of models. It can be in the form of textbook or course book, newspaper, website, audio video, picture, and so forth. In detail, he classifies the kind of materials into five types namely: 1) informative, 2) instructional, 3) experimental, 4) eliciting, and 5) exploratory. Informative materials refer to materials that inform the students about the target language. Instructional materials mean the materials that guide the students to practice the language they learn. For experimental materials, they refer to any attempts to provide the students with some experiences of the language in use. The eliciting materials tend to encourage the students to use the language. The last, for the exploratory materials emphasize on helping students to make discoveries about the language.

On the other hand, Local wisdom is a local idea or traditional thought which is full of wisdom, discernment, good value that have been embedded and followed by the society members. In other word, local wisdom is a product of the past cultural heritage that covers philosophy of values, ethics, and behavioral ways that traditionally work (Nugraheni, et al. 2016). The values of local wisdom are believed by the society as a good and right concept in carrying out their daily life. Similarly, Meliono (2011) states that local wisdom is a form of expression of the people or ethnics which do their activities and behave accordingly adjusted to the idea which is generally applicable in that place.

Addressing local wisdom materials in ELT is believed to be one of strives to conserve and appreciate the cultural heritage. Moreover, applying local wisdom is beneficial to help the students in gaining cultural acquisition, and positive values for their character building (Prasetyo, 2016). In the Indonesian context, English language teaching should not simply let students copy foreign cultures in their communication learning, but importantly reflect an understanding to norms and values incorporating a sense of national integrity in their English proficiency, characterizing them as Indonesians in the global community (Septy, 2016). Therefore, managing the local wisdom materials in the ELT in the Indonesian context should be considered by the teacher.

Referring to the previous explanation, it would be more advantageous to insert the local culture or local wisdom values and norms in practicing English language learning. The integration of local wisdom can be an alternative way in introducing the students' cultural background and identity (Prasetyo, 2016; Septy, 2016; Sudartini, 2012). It is also hoped to strengthen the students' nationalism awareness when they contact or learn a foreign culture 
Badrut Tamam, Slamet Setiawan, Syafi'ul Anam, Jihat Nurrahman,

Tell : Teaching of English Language and Literature Journal

Vol. 8, No. 1, 28 - 39, Doi: http://dx.doi.org/10.30651/tell.v8i1.4410

ideology influenced in the English teaching practice (Parmin et al., 2015; Septy, 2016). In this case, the teacher should consider what kind of local wisdom can be integrated in teaching English.

\section{Methodology}

As the objective of the research to describe students' perception on teaching materials of English for Education department, this research was classified as descriptive research. To get the answers of the research questions, a survey was distributed to the students in the first semester of Mathematics Education Department of a private higher education college in Sumenep Madura exactly in the academic year 2019/2020. There were 34 respondents who involved in this study.

This research was triangulated with three instruments used in collecting data such as: questionnaire, observation field notes, and interview. First of all, the researcher sat into the classroom for recording data through observation sheets during the implementation of culinary based teaching materials of English. The process had been conducted in one meeting. The activity of English Language Teaching (ELT) by using Madurese culinary materials was begun by dividing the students into some groups. Then, the descriptive text containing the descriptions of Madurese culinary were distributed by the lecturer to each group. Each group had different variety of Madurese culinary description. The students were asked to read the text in the several minutes to recognize the content, the language features, and the generic structures. To examine the students' comprehension about the text, the lecturer prepared some questions related to the text in the term of quiz. The group that could answer appropriately, the lecturer would give a score as the reward in that quiz. After the implementation, the students were asked to give responses on several items in the questionnaire. The phase was expected to know their perception towards Madurese culinary based teaching materials of English.

The questionnaire employed two kinds of questions, namely closed and open questions. Likert scale with 4 options: strongly agree, agree, disagree and strongly disagree, had been used in close questions focusing on materials' attraction, materials' usefulness, materials' difficulty, materials' variety, materials' authenticity, and proportion of the four language skills. Furthermore, to confirm the students' responses in the questionnaire, the researcher invited some students to be interviewed.

After collecting the data, the next stage was analyzing the data. Based on the view of Bogdan \& Biklen (2007) and Creswell (2014), data analysis is the process of systematical searching and arranging the interview transcript, field-notes, questionnaire, and other materials which were accumulated to obtain the comprehensive understanding of them into manageable units, synthesizing, and formulating the patterns. All of the data gained from the observation field note, questionnaire, and interview, would be analyzed descriptively.

\section{Findings and Discussion}

Findings

The concern of this research was to know the students' perception towards Madurese traditional culinary-based teaching materials in ELT. 34 students of higher education in the private college in Sumenep Madura had full-filled the questionnaire which consisted of 17 items of statements and 
Badrut Tamam, Slamet Setiawan, Syafi'ul Anam, Jihat Nurrahman,

Tell : Teaching of English Language and Literature Journal

Vol. 8, No. 1, 28 - 39, Doi: http://dx.doi.org/10.30651/tell.v8i1.4410 questions with four options, namely: strongly agree, agree, disagree, and strongly disagree. The questionnaire items consisted of seven factors. They were: 1) Material attraction; 2) Material usefulness; 3) Material difficulty; 4) Material variety; 5) Material authenticity; 6) four skills proportion; and 7) Students' Perception of English Materials by using Madura Traditional Culinary. As the data was collected by distributing a questionnaire to the respondents, the results are presented as follows:

Table 1

Material Attraction

\begin{tabular}{|c|c|c|c|c|c|}
\hline \multirow[b]{2}{*}{ Statement } & \multicolumn{4}{|c|}{ Response } & \multirow[b]{2}{*}{ Total } \\
\hline & $\begin{array}{l}\text { Strongly } \\
\text { Agree }\end{array}$ & Agree & Disagree & $\begin{array}{l}\text { Strongly } \\
\text { disagree }\end{array}$ & \\
\hline $\begin{array}{l}\text { The materials of English by using Madurese } \\
\text { traditional culinary is interesting for me. }\end{array}$ & $50 \%$ & $50 \%$ & & & $100 \%$ \\
\hline $\begin{array}{l}\text { By implementing Madurese traditional } \\
\text { culinary based teaching materials makes me } \\
\text { motivated to learn English. }\end{array}$ & $35 \%$ & $53 \%$ & $12 \%$ & & $100 \%$ \\
\hline $\begin{array}{l}\text { By implementing Madurese traditional } \\
\text { culinary based teaching materials, I enjoy } \\
\text { learning English. }\end{array}$ & $53 \%$ & $47 \%$ & & & $100 \%$ \\
\hline $\begin{array}{l}\text { This model should be applied by the } \\
\text { teacher/lecturer in teaching English. }\end{array}$ & $29 \%$ & $59 \%$ & $12 \%$ & & $100 \%$ \\
\hline
\end{tabular}

Table 2

Material Usefulness

\begin{tabular}{|c|c|c|c|c|c|}
\hline \multirow[b]{2}{*}{ Statement } & \multicolumn{4}{|c|}{ Response } & \multirow[b]{2}{*}{ Total } \\
\hline & $\begin{array}{c}\text { Strongly } \\
\text { Agree }\end{array}$ & Agree & Disagree & $\begin{array}{l}\text { Strongly } \\
\text { disagree }\end{array}$ & \\
\hline $\begin{array}{l}\text { The materials using Madurese traditional } \\
\text { culinary is beneficial for me in mastering } \\
\text { English. }\end{array}$ & $38 \%$ & $57 \%$ & $5 \%$ & & $100 \%$ \\
\hline $\begin{array}{l}\text { The materials of English by using Madurese } \\
\text { traditional culinary helps me to understand } \\
\text { some terms that I find in other subjects. }\end{array}$ & $47 \%$ & $53 \%$ & & & $100 \%$ \\
\hline $\begin{array}{l}\text { The materials of English by using Madurese } \\
\text { traditional culinary helps me to identify my } \\
\text { local culinary deeper. }\end{array}$ & $70 \%$ & $30 \%$ & & & $100 \%$ \\
\hline $\begin{array}{l}\text { The materials of English by using Madurese } \\
\text { traditional culinary helps me to identify my } \\
\text { identity. }\end{array}$ & $50 \%$ & $50 \%$ & & & $100 \%$ \\
\hline $\begin{array}{l}\text { The materials of English by using Madurese } \\
\text { traditional culinary help me to know some } \\
\text { new knowledge. }\end{array}$ & $38 \%$ & $62 \%$ & & & $100 \%$ \\
\hline $\begin{array}{l}\text { The materials of English by using Madurese } \\
\text { traditional culinary develops my English } \\
\text { skill. }\end{array}$ & $35 \%$ & $40 \%$ & $20 \%$ & $5 \%$ & $100 \%$ \\
\hline
\end{tabular}


Badrut Tamam, Slamet Setiawan, Syafi'ul Anam, Jihat Nurrahman,

Tell : Teaching of English Language and Literature Journal

Vol. 8, No. 1, 28 - 39, Doi: http://dx.doi.org/10.30651/tell.v8i1.4410

Table 3

Material Difficulty

\begin{tabular}{|c|c|c|c|c|c|}
\hline \multirow[b]{2}{*}{ Statement } & \multicolumn{4}{|c|}{ Response } & \multirow[b]{2}{*}{ Total } \\
\hline & $\begin{array}{c}\text { Strongly } \\
\text { Agree }\end{array}$ & Agree & Disagree & $\begin{array}{l}\text { Strongly } \\
\text { disagree }\end{array}$ & \\
\hline $\begin{array}{l}\text { I think the materials of English by using } \\
\text { Madura's Traditional culinary is accordance } \\
\text { with my competence }\end{array}$ & $24 \%$ & $44 \%$ & $32 \%$ & & $100 \%$ \\
\hline $\begin{array}{l}\text { By implementing Madurese traditional } \\
\text { culinary based teaching materials, learning } \\
\text { English becomes easy. }\end{array}$ & $24 \%$ & $44 \%$ & $32 \%$ & & $100 \%$ \\
\hline
\end{tabular}

Table 4

Material Variety

\begin{tabular}{lcccc}
\hline \multirow{2}{*}{ Statement } & \multicolumn{3}{c}{ Response } \\
\cline { 2 - 3 } & $\begin{array}{c}\text { Strongly } \\
\text { Agree }\end{array}$ & Agree & Disagree & $\begin{array}{c}\text { Strongly } \\
\text { disagree }\end{array}$ \\
\hline $\begin{array}{l}\text { The kinds of Madurese culinary covered in } \\
\text { English materials is varied }\end{array}$ & $83 \%$ & $17 \%$ & $100 \%$ \\
\hline
\end{tabular}

Table 5

Material Authenticity

\begin{tabular}{lcccc}
\hline \multicolumn{1}{c}{ Statement } & \multicolumn{3}{c}{ Response } \\
\cline { 2 - 4 } & $\begin{array}{c}\text { Strongly } \\
\text { Agree }\end{array}$ & Agree & Disagree & $\begin{array}{c}\text { Strongly } \\
\text { disagree }\end{array}$ \\
\hline $\begin{array}{l}\text { The materials of English by using Madurese } \\
\text { traditional culinary cover authentically daily } \\
\text { life topics }\end{array}$ & $58 \%$ & $42 \%$ & & $100 \%$ \\
\hline
\end{tabular}

Table 6

4 Skills proportion

\begin{tabular}{lcccc}
\hline \multicolumn{1}{c}{ Statement } & \multicolumn{2}{c}{ Response } \\
\cline { 2 - 3 } & $\begin{array}{c}\text { Strongly } \\
\text { Agree }\end{array}$ & Agree & Disagree & $\begin{array}{c}\text { Strongly } \\
\text { disagree }\end{array}$ \\
\hline $\begin{array}{l}\text { The materials of English by using Madurese } \\
\text { traditional culinary have covered the four }\end{array}$ & $44 \%$ & $56 \%$ & & $100 \%$ \\
English skill & & & \\
\hline
\end{tabular}

In part 2, the questionnaire puts two open questions asking about students' opinion about whether the implementation can be assumed as the step to preserve local wisdom, and what the advantages from the implementation are. 
Badrut Tamam, Slamet Setiawan, Syafi'ul Anam, Jihat Nurrahman,

Tell : Teaching of English Language and Literature Journal

Vol. 8, No. 1, 28 - 39, Doi: http://dx.doi.org/10.30651/tell.v8i1.4410

Table 7

Students' Perception of English Materials by using Madurese Traditional Culinary

\begin{tabular}{lll}
\hline No. & \multicolumn{1}{c}{ Questions } & \multicolumn{1}{c}{ Responses } \\
\hline 1. & $\begin{array}{l}\text { According to your opinion, is the implementation } \\
\text { classified as the step to preserve local wisdom } \\
\text { especially in Madurese culinary? Why }\end{array}$ & $\begin{array}{l}\text { Yes. The student is introduced to the various } \\
\text { Madurese culinary, then they love Madurese } \\
\text { culinary. }\end{array}$ \\
2. What are the advantages of the implementation? & $\begin{array}{l}\text { I know more about various Madurese culinary } \\
\text { By implementing Madurese traditional culinary } \\
\text { based teaching materials, additionally, I enjoy } \\
\text { learning English. Furthermore, traditional } \\
\text { culinary can be used as the identity that can } \\
\text { promote the region to the outside world. }\end{array}$ \\
\hline
\end{tabular}

\section{Discussion}

The result from 34 respondents' through questionnaire indicates the students give a positive perception toward Madurese culinary-based teaching materials after they have joined the teaching process. It can be seen through the data that $100 \%$ of English student agree that materials based Madurese traditional culinary is interesting, then $88 \%$ of the students feel motivated, happy, and interested in joining the English class. Further, $100 \%$ of them enjoy the English teaching process, and $88 \%$ of them propose many other lecturers or teachers to apply in different local traditional culinary. The content of the materials also help the students to know deeper about their local culinary, new knowledge, and their identity. It is in accordance with Prasetyo's finding (2016). Majority of the students obtain some benefits, they become easy in mastering English, the materials are accordance with their ability, and they can improve the four skills competency of English (Reading, Listening, Speaking, and Writing). In addition, they perceive that the implementation of Madurese traditional culinarybased teaching materials is a good step to preserve and maintain their local identity. It is in line with theory proposed by (Bakhtiar et al., 2016; Sa-ngiamwibool, 2012; Wardani et al., 2016). Additionally, traditional culinary can be used as the identity that can promote the region to the outside world (Aryanti, 2010).

In order to ensure the students responses in the questionnaire, the researcher directly observed the teaching process during the implementation of the Madurese culinary materilas. The researchers' field note records some important occurrences such as: 1) all the students are happy during the teaching and learning process. They allow the lecturer's instruction, such as when the lecturer divides the class into some groups and gives time allocation for reading the text, the students are enthusiastic to pay attention to the lecturer. 2) The students are very enthusiastic in reading the text, and finding a meaning of some missing words using their dictionary. 3) They also discuss in group about the uniqueness of the culinary from the text that they had been red. 4) However, they have problem with vocabulary, it looks when the lecturer delivers some questions to the group, sometimes they are confused to answer because they do not know the point of the question. 5) The students are very motivated to 
Badrut Tamam, Slamet Setiawan, Syafi'ul Anam, Jihat Nurrahman,

Tell : Teaching of English Language and Literature Journal

Vol. 8, No. 1, 28 - 39, Doi: http://dx.doi.org/10.30651/tell.v8i1.4410

answer the teacher's question which is delivered to the group even though the vocabulary used to answer is not appropriate.

Furthermore, the researcher interviews three students to confirm their responses in the form of questionnaire. The students express that they are interested and motivated to join the ELT class. Similarly, they enjoy the process of teaching English by using Madurese culinarybased materials. Further, the students are easily able to understand the variety of Madurese culinary, new vocabulary of several words, and the new knowledge related their local identity. When they are asked, whether the implementation of Madurese culinary based teaching materials are classified as a good way or not to preserve the local wisdom of Madura, all of them confidently answer "Yes, it is one of the steps to maintain the existence of local wisdom especially in Madura in term of culinary". It means the step which has been conducted by the teacher is a proper step to preserve local wisdom of Madura. In addition, they agree with what the teacher has done.

Based on the overall data presented on the previous parts, it could be seen that the English learning material which was equipped with Madurese popular culinary got a positive perception and higher appreciation from the students in terms of materials' attraction, materials' usefulness, materials' difficulty, materials' variety, materials' authenticity, and proportion of the four language skills. They said that they could recognize the madurese culinary deeper than before. In other words, the learning materials with cover traditional culinary of Madura motivate them to learn English. They enjoyed the activity of classroom learning. In addition, the students agree that it is the great way to preserve and maintain local wisdom, especially in term of Madurese traditional culinary.

\section{Conclusion}

Based on the research finding, the conclusion can be drawn as follow: (1) Students give a positive perception and higher appreciation from the students in terms of materials' attraction, materials' usefulness, materials' difficulty, materials' variety, materials' authenticity, and proportion of the four language skills. 100\% of English students agree that English materials based Madurese traditional culinary is interesting, then $88 \%$ of the students feel motivated, happy, and interested in join the English class. Further, $100 \%$ of them enjoy the English teaching process, and $88 \%$ of them propose many other lecturers or teachers to apply in different local traditional culinary. The content of the materials also help the students to know deeper about their local culinary, new knowledge, and their identity. Moreover, they are very enthusiastic in joining the class of English language learning. They can also recognize several kinds of Madurese culinary. (2) The students assume that the implementation of Madurese traditional curinary-based teaching materials as a good way to preserve local wisdom notably in Madurese traditional culinary. For the recommendation, it is important to develop a further product of culture-based English learning because there are so many positive values inside the culture. As a way of life, culture brings a very significant role to the human life. 


\section{References}

Badrut Tamam, Slamet Setiawan, Syafi'ul Anam, Jihat Nurrahman,

Tell : Teaching of English Language and Literature Journal Vol. 8, No. 1, 28 - 39, Doi: http://dx.doi.org/10.30651/tell.v8i1.4410

Afifah, W. (2015). Incorporating Cultures in English Learning Materials to Enhance the Internalization and Actualization of Culture Values toward Junior High School Incorporating Cultures in English Learning Materials to Enhance the Internalization and Actualization of Cult. International Conference on Educational Research and Innovation (ICERI) Yogyakarta State University.

Aryanti, N. (2010). Using Palembang's Traditional Foods as English Teaching Materilas: A theme-Based Language Instruction. Holistics, 2(4).

Bakhtiar, A. M., \& Nugroho, A. S. (2016). Curriculum Development of Environmental Education Based on Local Wisdom at Elementary. International Journal of Learning, Teaching and Educational Research, 15(3), 20-28.

Bogdan, R. C., \& Biklen, S. K. (2007). Qualitative Research for Education An Introduction to Theory and Methods Fifth Edition. USA: Person Education Group, Inc.

Creswell, W. J. (2014). Research Design: Qualitative, Quantitative, and Mixed methods Approach 4 Edition. London: SAGE Publications.

Latupapua, M. S. (2018). Implementing Traditional Food of Maluku in Teaching Procedure Text For The Tenth Grade of SMK Negeri 1 Ambon. Jurnal Tahuri, 15(2), 9-16.

Meliono, I. (2011). Understanding the Nusantara Thought and Local Wisdom as an Aspect of the Indonesian Education. TAWARIKH: International Journal for Historical Studies, 2(2), 221-234.

Parmin, Sajidan, Ashadi, \& Sutikno. (2015). Skill of Prospective Teacher in Integrating the Concept of Science with Local Wisdom Model. Indonesian Journal of Science Education, 4(2), 120-126. https://doi.org/10.15294/jpii.v4i2.4179

Parmin, Sajidan, Ashadi, Sutikno, \& Maretta, Y. (2016). Preparing Prospective Teachers in Integrating Science and Local Wisdom through Practicing Open Inquiry. Journal of Turkish Science Education, 13(2), 3-14. https://doi.org/10.12973/tused.10163a

Prasetyo, A. (2016). Prasteyo_local wisdom.pdf. Journal of ELT Research, 1(2), 194-199.

Sa-ngiamwibool, A. (2012). Raising Learner Awareness of Local Wisdom in Tour-Related Project Teaching. Indonesian Journal of Applied Linguistics, 1(2), 1-16.

Septy, A. P. (2016). Managing Local Wisdom in English Teaching Materials. In Proceedings of the Fourth International Seminar onEnglish Language and Teaching (ISELT-4) (pp. 81-88).

Sudartini, S. (2012). Inserting Local Culture in English Language Teaching to Promote Character Education. Jurnal Pendidikan Karakter, 1, 45-54.

Suhaidi, M., Dewi, I. Y. M., \& Muslim, M. (2018). Sumenep The Soul of Madura. Sumenep: Dinas Pariwisata, Kebudayaan, Pemuda, dan Olahraga.

Tomlinson, B. (2016). The importance of materials development for language learning. In Issues in materials development. Rotterdam: Sense Publisher.

Wardani, N. E., Widyahening, E. T., \& Suhita, R. (2016). Learning Media Using Wayang Wong to Introduce Local Wisdom of Javanese Culture for the Students of Indonesian Language for Foreign Learners. Journal of Arts, Science \& Commerce, 7(3), 48-53.

Yoda, I. K. (2017). The Development of Cooperative Learning Model Based on Local Wisdom of Bali for Physical Education, Sport and Health Subject in Junior High The Development of Cooperative Learning Model Based on Local Wisdom of Bali for Physical Education, Sport and Hea. IOP Conference Series: Materials Science and Engineering, 180(1), 1-8. https://doi.org/10.1088/1742-6596/755/1/011001 